\title{
ANÁLISE SOBRE A \\ ABORDAGEM DA EDUCAÇÃO \\ AMBIENTAL EM SELETOS \\ CURSOS DE UMA INSTITUIÇÃO \\ DE ENSINO SUPERIOR
}

\author{
Arielle da Rosa Sousa ${ }^{1}$ \\ Vandressa Siqueira Walerko² \\ Érico Kunde Corrêa ${ }^{3}$ \\ Luciara Bilhalva Corrêa ${ }^{4}$
}

Resumo: A Educação Ambiental é elemento fundamental e permanente para a educação, em que deve estar inserida, de forma articulada, em todos os níveis e modalidades do processo educacional. Diante disso, buscou-se verificar a presença de questões ambientais em 83 cursos de uma Instituição de Ensino Superior, através da análise de seus Projetos Pedagógicos e disciplinas. Revelou-se que $73,49 \%$ dos cursos não fazem menção à Política Nacional da Educação Ambiental em seus projetos, e 33,73\% não possuem disciplinas com abordagem ambiental em sua matriz curricular. Dessa forma, acredita-se que Universidade deve reforçar seu papel como unidade formadora de cidadãos, promovendo a inserção da temática ambiental nos mais diversos cursos.

Palavras-chave: Educação Ambiental; Política Nacional da Educação Ambiental; Projeto Pedagógico de Curso.

Abstract: Environmental Education is a fundamental and permanent element for education, in which it must be inserted, in an articulated way, at all levels and modalities of the educational process. Therefore, this paper sought to verify the presence of environmental matter in 83 courses of a Higher Education Institution, through the analysis of its Pedagogical Projects and disciplines. It was revealed that $73.49 \%$ of the courses do not mention the National Policy for Environmental Education in their projects and $33.73 \%$ do not have subjects with an environmental approach in their curriculum. Thus, it is believed that the University should reinforce its role as a unit that educates citizens, fomenting the insertion of the environmental studies theme in diverse courses.

Keywords: Environmental Education; National Policy for Environmental Education; Pedagogical Course Project.

\footnotetext{
1 Universidade Federal de Pelotas. E-mail: ariellesousa.as@gmail.com.

2 Universidade Federal de Pelotas. E-mail: vandressawalerko@gmail.com.

3 Universidade Federal de Pelotas. E-mail: ericokundecorrea@yahoo.com.br.

${ }^{4}$ Universidade Federal de Pelotas. E-mail: luciarabc@gmail.com.
} 


\section{Introdução}

A Educação Ambiental (EA) mostra-se como uma das principais ferramentas no combate à crise ambiental atualmente, por meio da prevenção de inúmeros fatores interferentes através da conscientização da população. Em frente às diversas definições para EA, destaca-se a de Medina (1994), que a descreve como um processo cujo objetivo é oferecer aos indivíduos uma compreensão crítica e global do ambiente, de modo que esses compreendam valores e atitudes conscientes quanto à conservação e preservação dos recursos naturais.

De acordo com a Constituição Federal, decretada em 1988, é obrigatória a inclusão da EA em disciplinas em todos os níveis de ensino (BRASIL, 1988). Ademais, em 27 de abril de 1999 foi decretada a lei no 9.795 que, além de outras providências, institui a Política Nacional da Educação Ambiental (PNEA), representando um marco fundamental para a consolidação da EA no país (BRASIL, 1999).

Através da promulgação dessa lei, ficou estabelecido que a EA é elemento fundamental e permanente para a educação, na qual essa deve estar inserida, de forma articulada, em todos os níveis e modalidades do processo educacional, tanto de caráter formal quanto informal. Nessa perspectiva, a EA entra como um instrumento, de processo contínuo, interdisciplinar e direcionado à toda a sociedade, visando o combate à degradação ambiental a partir do contexto educacional, diante da elaboração de propostas que provoquem mudanças no cenário socioambiental, contribuindo para 0 desenvolvimento sustentável (BRASIL, 1999; CARVALHO et al., 2015).

Nesse cenário, no Art. 10 da PNEA, determina-se que a EA deve ser desenvolvida como "prática educativa integrada, contínua e permanente em todos os níveis e modalidade do ensino formal", englobando o ensino superior. Também fica decretado no parágrafo $1^{\circ}$ desse artigo que a EA não deve ser implantada como disciplina específica, com exceção nos cursos de pósgraduação, extensão e áreas voltadas ao aspecto metodológico da educação, no qual é facultativa a criação da disciplina, como determinado no parágrafo $2^{\circ}$ (BRASIL, 1999).

A Conferência Intergovernamental sobre Educação Ambiental, organizada pela Unesco no ano de 1977 enfatiza em seu texto que a promoção da EA nas universidades é essencial para conscientizar as pessoas sobre as questões ambientais. Como apontado por Morales (2007), a universidade como instituição de educação técnica e superior tem função primordial na construção de saberes, sendo assim, é essencial uma maior responsabilização no processo de inserção da dimensão ambiental na formação profissional e educacional.

Para tanto, é importante apontar que, de acordo com o estabelecido pelo Programa Nacional de Educação Ambiental (ProNEA) (BRASIL, 2005), a inclusão da EA em Instituições de Ensino Superior (IES) deve ocorrer através 
de incentivo de implementação de projetos de extensão universitária com enfoque neste tema, além de retorno dos resultados das pesquisas e estudos às comunidades envolvidas. Além disso, é proposta a inclusão de disciplinas sobre o "meio ambiente", tornando esse tema transversal ao ensino, pesquisa e extensão. De modo complementar, no Art. 11 da PNEA, impõe-se que a temática ambiental deve estar imersa nos currículos de formação de professores, em todos os níveis e disciplinas (BRASIL, 1999).

Outro marco fundamental na política ambiental no país ocorreu em agosto de 2010, com a promulgação da Política Nacional de Resíduos Sólidos (PNRS). Essa lei serve como ferramenta face às problemáticas que envolvem os resíduos sólidos no país, cujos instrumentos e diretrizes foram definidos de modo a auxiliar tal empecilho. Nesse sentido, cabe mencionar os Planos de Resíduos, que podem ser elaborados em nível nacional, estadual, regional e de gerenciamento (no caso de geradores definidos no Art. 20 da PNRS), a ordem de prioridade na gestão e gerenciamento de resíduos, que segue: "não geração, redução, reutilização, reciclagem, tratamento dos resíduos sólidos e, por fim, disposição final ambientalmente adequada dos rejeitos", além do reconhecimento da EA como um de seus instrumentos (BRASIL, 2010).

Porém, apesar de ter passado nove anos desde o decreto da referida lei, ainda há muitas questões a se evoluir. Nesse sentido, desde a inauguração de um Restaurante Universitário (RU) em meados de maio de 2018, a disposição inadequada de resíduos orgânicos se mostrou um transtorno recorrente no município de Pelotas/RS. Isso porque diversos estudantes da Universidade Federal de Pelotas (UFPel), após realizarem suas refeições, têm depositado as cascas e restos das frutas oferecidas como sobremesa nos canteiros nas proximidades do RU (DIÁRIO POPULAR, 2018).

A disposição inadequada de resíduos sólidos em vias públicas acarreta a obstrução de vias de microdrenagem, contribuindo na ocorrência de alagamentos em períodos chuvosos. Além disso, na presença de matéria orgânica, ocorre a liberação de chorume e, concomitantemente, a contaminação das águas de escoamento, assim como atração e proliferação de vetores de doenças e patógenos, representando um problema para a saúde pública (BRAGA et al., 2002; DALTOÉ et al., 2016).

Frente à problemática supracitada, este estudo faz parte de um projeto que analisou a percepção ambiental dos discentes usuários dos RUs da UFPel. Para tanto, foi realizada a aplicação de um questionário, no qual uma quantidade de 380 alunos de diversos cursos participou respondendo questões referentes à disposição inadequada de resíduos orgânicos. A partir daí, o presente artigo parte para a busca da abordagem da temática da EA nos cursos participantes da pesquisa, para então realizar uma análise de como vem sendo tratadas as questões ambientais no ambiente acadêmico da referida Universidade. Sendo assim, definiu-se o seguinte objetivo: verificar a abordagem de Educação Ambiental presente nos Projetos Pedagógicos de Curso (PPC) e disciplinas que englobam a temática ambiental. 


\section{Metodologia}

Para o desenvolvimento do estudo transversal, optou-se por uma pesquisa descritiva de abordagem quali-quantitativa. Nesse sentido, foi realizada uma análise documental do Projeto Político Pedagógico - PPP (ou Projeto Pedagógico de Curso - PPC) dos cursos dos estudantes que participaram de um estudo maior, sobre a percepção ambiental de discentes quanto à disposição inadequada de resíduos orgânicos nos arredores de um Restaurante Universitário da UFPel (GIL, 2007; GERHARDT; SILVEIRA, 2009).

Segundo o Portal Institucional da UFPel (2019), a Universidade conta atualmente com um total de 20.827 estudantes, sendo estes distribuídos entre 96 cursos de Graduação (com 16.461 discentes matriculados), 3 de Educação à Distância (EAD) (1.763 discentes), 26 Doutorados (1.034 discentes), 50 Mestrados (1.174 discentes), 34 Especializações (285 discentes) e 6 Mestrados Profissionais (110 discentes).

O tamanho da amostra do questionário aplicado aos estudantes foi determinado com base no método estatístico de determinação da estimativa populacional a partir da proporção populacional, dado pela Equação 1:

$$
n=\frac{N \times Z_{\alpha / 2}^{2} \times \hat{p} \times \hat{q}}{(N-1) \times E^{2}+Z_{\alpha / 2}^{2} \times \hat{p} \times \hat{q}}
$$

Cujos símbolos representam:

- $n$ = Número de indivíduos na amostra;

- $N=$ Número de indivíduos na população;

- $Z_{\alpha / 2}=$ Valor crítico correspondente ao grau de confiança;

- $\hat{p}=$ Proporção populacional de indivíduos na categoria de interesse;

- $\hat{q}=$ Proporção populacional de indivíduos que não pertencem à categoria de interesse $(\hat{q}=1-\hat{p})$;

- $E=$ Margem de erro ou erro máximo de estimativa

Segundo Levine (2000), quando os valores de $\widehat{p}$ e $\hat{q}$ são desconhecidos, deve-se adotar uma porcentagem para cada um correspondente a $50 \%$. A partir disso, foi selecionado um nível de significância de 95\% e uma margem erro de $5 \%$, com um valor crítico correspondente a 1,96. Portanto, calcula-se o valor da amostra:

$$
n=\frac{20827 \times 1,96^{2} \times 0,5 \times 0,5}{(20827-1) \times 0,05^{2}+1,96^{2} \times 0,5 \times 0,5}=377,22
$$

Realizando o cálculo, chega-se ao valor de 377,22, o qual foi arredondado, totalizando uma amostra de 380 entrevistados. Para alcançar o número de amostra, o questionário foi disponibilizado através da plataforma

revista brasileira educação ambiental 
Google Forms, de forma online em um grupo de uma rede social que participam estudantes da UFPel, durante o período de 31 de julho a 7 de setembro de 2018.

Após a coleta das respostas obtidas pelo questionário, os dados foram tabulados em uma planilha do Programa Microsoft Excel, no qual foi possível quantificar alunos e cursos participantes, encontrando-se um valor total de 83 cursos. A partir disso, foi realizada uma pesquisa bibliográfica, no período entre 20 de março e 7 de junho de 2019, analisando todos os PPCs que estavam disponíveis nos sites dos cursos que participaram da pesquisa, priorizando-se a análise do documento mais atual, quando na presença de mais de um PPC.

Nessa análise, objetivou-se investigar a menção da PNEA e como a EA estaria inserida na grade curricular dos cursos em questão. Além disso, foram analisadas disciplinas, tanto obrigatórias quanto optativas, que possuíam caráter ambiental, observando seus Objetivos Gerais e Ementa. Portanto, foi realizada uma busca pelos termos "Política Nacional da Educação Ambiental" e "PNEA" para verificar sua presença no PPC, além dos termos "natureza", "meio ambiente", "Educação Ambiental", "gestão ambiental", "licenciamento ambiental", "impacto ambiental", "sustentabilidade", "ecologia", "manejo e conservação de recursos naturais" e algumas variantes para verificar as disciplinas com abordagem ambiental.

Esses resultados foram novamente tabulados no Programa Microsoft Excel, possibilitando visualizar de modo qualitativo a presença das disciplinas supracitadas, assim como seus conteúdos. Diante da presença de cursos voltados diretamente à área ambiental, como Agronomia, Engenharia Ambiental e Sanitária, e Gestão Ambiental, limitou-se a uma quantidade máxima de apresentação de quatro disciplinas por curso, com seus respectivos Objetivos Gerais e Ementas. Para os cursos que possuíam um valor superior, algumas disciplinas foram citadas. Já cursos que não possuíam disciplinas não foram incluídos nas tabelas, mas serão discorridos ao longo do estudo.

\section{Resultados e discussão}

A partir dos resultados do questionário totalizou-se 83 cursos participantes, distribuídos em 71 Cursos de Graduação (85,5\%) - sendo 54 bacharelados (65,1\%), 12 licenciaturas (14,5\%) e 5 tecnológicos (6,0\%) - além de 12 Programas de Pós-Graduação (PPG) (14,5\%).

De modo a aprimorar a visualização dos resultados quanto à presença da PNEA nos PPCs e das disciplinas com abordagem ambiental, estes foram organizados em gráficos, que seguem nas Figuras 1 e 2 . 


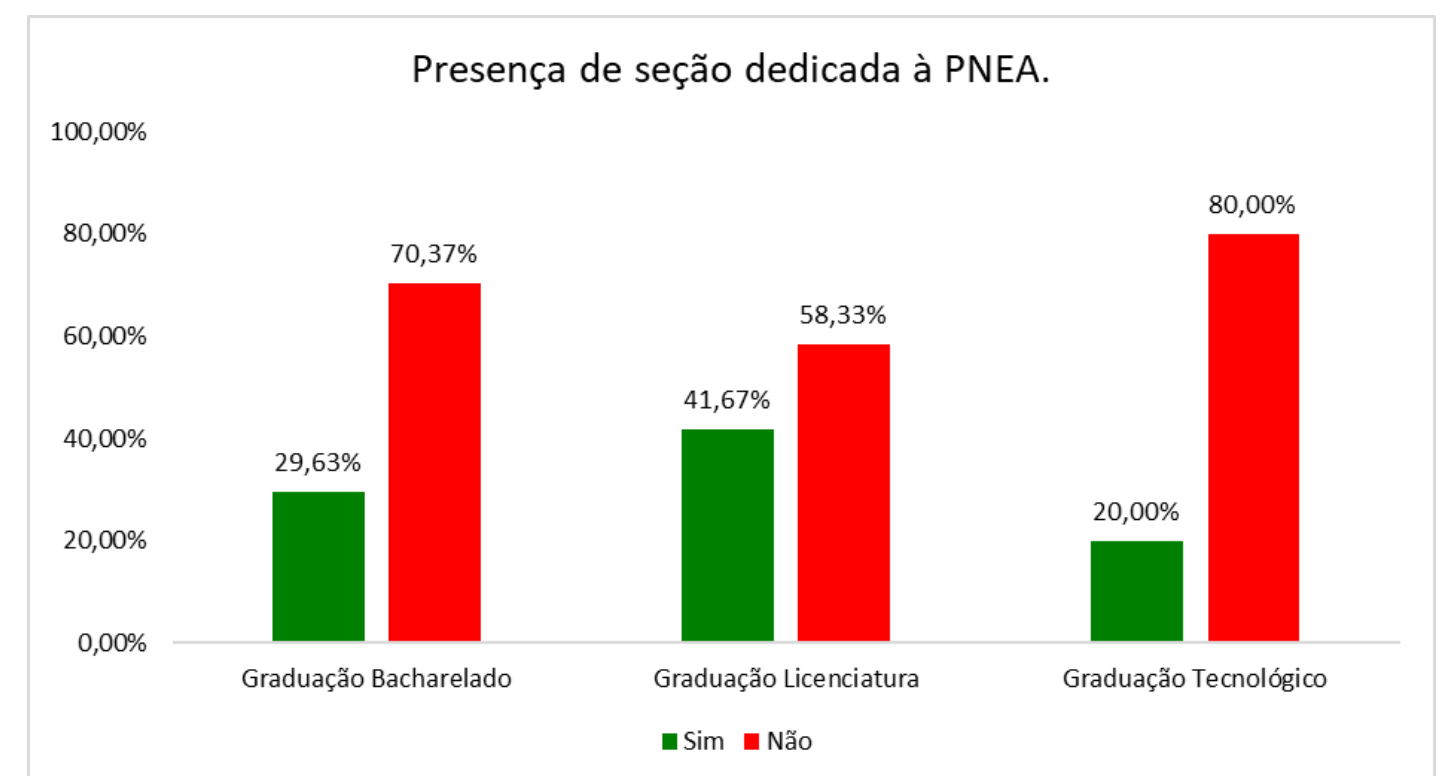

Figura 1: Presença de seção dedicada à Política Nacional da Educação Ambiental nos PPCs dos cursos participantes do estudo. Fonte: autoria própria.

Deve-se ressaltar que os 12 cursos que são PPG não foram incluídos na Figura 1 por não possuírem um PPC, e sim um Regimento que não inclui legislações a serem observadas ao longo da formação, portanto não foi possível averiguar a presença da PNEA nesses. Nesse cenário, a partir da análise da Figura 1, observa-se a ausência de menção à PNEA em grande parte dos cursos de Graduação, mais detalhadamente, em $80 \%$ dos cursos Tecnológicos, em $70,37 \%$ dos cursos Bacharelados e em $58,33 \%$ dos cursos de Licenciatura. Nesse cenário, soma-se um total de 61 cursos que não mencionam a PNEA, valor correspondente a $73,49 \%$ dos cursos participantes da pesquisa.

Deve-se ressaltar que destes 61 cursos, em 16 o PPC estava indisponível para visualização ou em construção, sendo esses: 3 cursos Tecnológicos (Alimentos, Gastronomia e Hotelaria), 12 cursos Bacharelados (Antropologia, Cinema de Animação, Cinema e Audiovisual, Design Digital, Design Gráfico, Enfermagem, História, Letras (Tradução Inglês-português), Medicina, Nutrição, Odontologia e Química Forense) e 1 curso de Licenciatura (História).

Segundo Veiga (2003), o Projeto Político-Pedagógico caracteriza-se como um documento programático, composto pelos objetivos, fundamentos, legislações a serem atendidas e orientações curriculares e organizacionais de um curso. Nesse sentido, é de fundamental importância a elaboração e disponibilização de um PPP por todos os cursos de uma IES, já que este "fornece uma direção e orienta o caminhar da ação docente, discente e dos gestores da instituição", além de propor práticas voltadas ao resgate de valores 
sociais e culturais, fornecendo instrumentos e ações a serem desenvolvidas através de uma proposta curricular integradora (AMEM; NUNES, 2006).

A partir disso, ressalta-se que 22 cursos de Graduação (30,98\% dos cursos participantes da pesquisa) incluem uma sessão dedicada à PNEA, sendo distribuídos em: 16 Bacharelados (Biotecnologia, Ciência da Computação, Ciências Sociais, Educação Física, Engenharia Ambiental e Sanitária (EAS), Engenharia da Computação, Engenharia de Controle e Automação, Engenharia de Produção, Engenharia Eletrônica, Engenharia Industrial Madeireira (EIM), Farmácia, Física, Letras Tradução PortuguêsEspanhol (TPE), Letras Redação e Revisão de Textos (RRT), Museologia e Terapia Ocupacional), 5 Licenciaturas (Educação Física, Física, Letras Português, Letras Português e Francês, e Letras Português e Inglês) e apenas 1 curso Tecnológico (Geoprocessamento).

Desses, 12 cursos apontam que a EA é aplicada "de modo transversal, em diversas disciplinas com enfoque interdisciplinar" ou em "disciplinas específicas"; em 2 cursos (Física Bacharelado e Licenciatura) através de "atividades de formação complementar"; em 6 cursos (EAS, EIM, Museologia, Letras Português, Português e Francês, e Português e Inglês), "de modo transversal, através de disciplinas específicas e projetos de ensino, pesquisa e extensão". E em 2 cursos (Letras TPE e Letras RRT) através de ações de conscientização entre os discentes, como diálogo sobre temáticas ambientais, promoção de consumo consciente, incentivo de reutilização e reciclagem de materiais, entre outros.

De acordo com o estabelecido na PNEA, a EA deve ser reconhecida como uma temática abordada no currículo, em todos os níveis e modalidade do ensino formal, de modo transversal e interdisciplinar. Segundo Leff (2001), há uma exigência de integração de conhecimentos para a aplicabilidade da EA, diante sua amplitude de conhecimentos distribuídos em diversas áreas científicas, através da interdisciplinaridade, promovendo intercâmbio entre esses campos.

Entretanto, de acordo com Bernardes e Prieto (2010), diversos estudos argumentam a importância da inclusão da disciplina específica de Educação Ambiental para produzir resultados mais efetivos em relação à conscientização dos indivíduos quanto às problemáticas ambientais da atualidade. Além disso, os autores apontam que a transversalidade não funciona na prática, devido à falta de garantia de sua aplicabilidade e à falta de capacitação, interesse ou conhecimento dos educadores para abordarem questões ambientais e realizarem projetos voltados à área. Outra vantagem da disciplinarização seria a visibilidade da Educação Ambiental, tornando possível a adoção de materiais didáticos específicos. 
Partindo desse cenário, os resultados da análise das disciplinas voltadas à temática ambiental, considerando os Objetivos Gerais e Ementa, foram ilustrados na Figura 2.

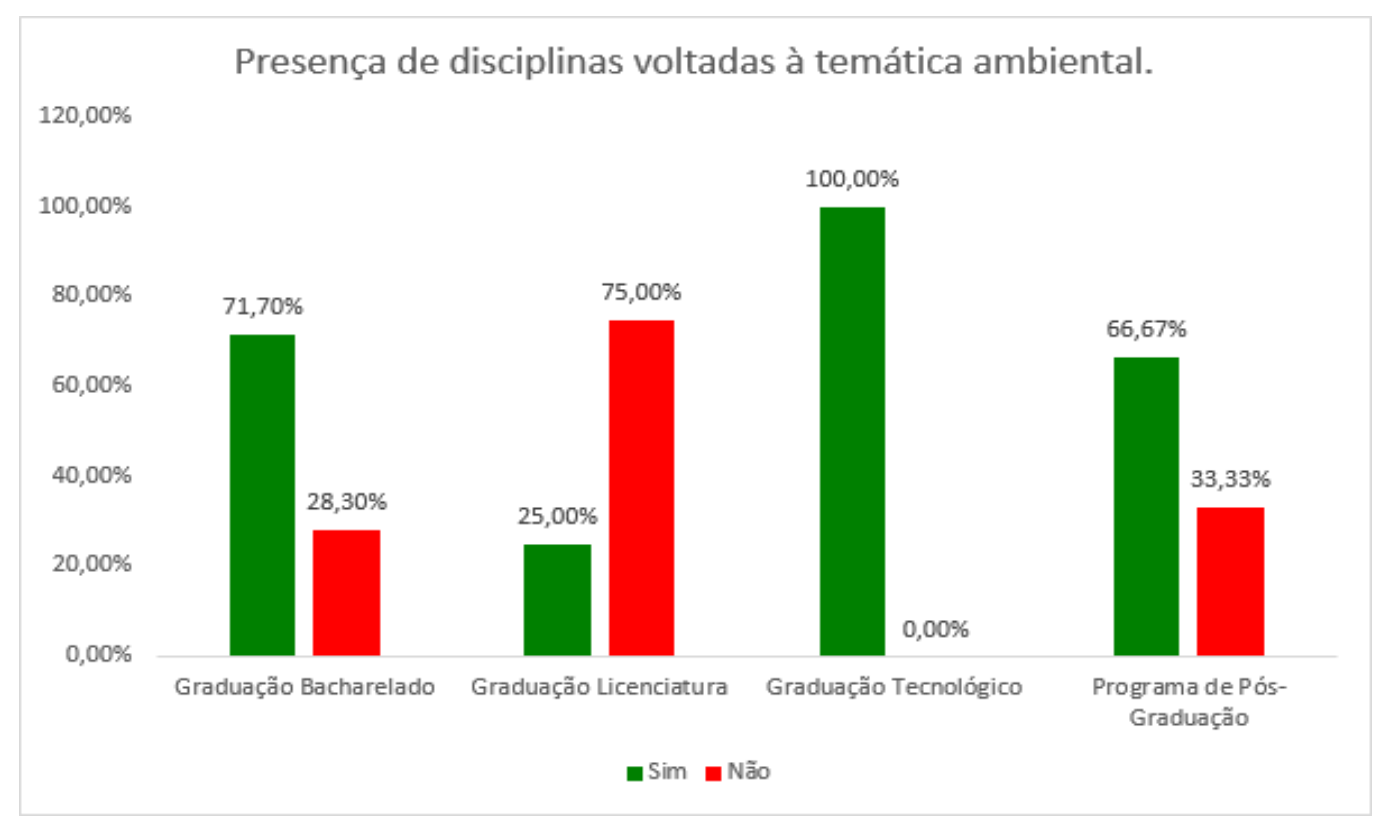

Figura 2: Presença de disciplinas voltadas à temática ambiental nos cursos participantes da pesquisa. Fonte: autoria própria.

Apesar da ausência de um PPC elaborado em 16 cursos, como discutido anteriormente, foi possível analisar as disciplinas de todos os cursos diante a disponibilização da matriz curricular de forma online nos sites ou no Portal Institucional da UFPel. De modo geral, $66,27 \%$ dos cursos participantes do estudo possuem disciplinas com abordagem ambiental, enquanto 33,73\% apresentam uma lacuna dessa temática em sua matriz curricular. Mais detalhadamente, com exceção dos cursos de Graduação - Licenciatura (25\%), mais da metade dos cursos possuem tais disciplinas, sendo estas encontradas em $100 \%$ dos cursos Tecnológicos, $71,70 \%$ dos cursos Bacharelados e $66,67 \%$ dos cursos de PPG.

Analisando individualmente, em relação aos cursos de Licenciatura, os cursos de Artes Visuais, Física, História, Letras (Português), Letras (Português e Francês), Letras (Português e Inglês), Matemática, Pedagogia e Teatro não foram encontradas disciplinas com abordagem ambiental. Apenas três cursos apresentam essa temática em suas respectivas matrizes curriculares, cujos temas estão expostos no Quadro 1. 
Quadro 1: Cursos de Graduação nível Licenciatura e disciplinas com temática ambiental.

\begin{tabular}{|c|c|c|c|}
\hline Curso & $\begin{array}{c}\text { Disciplina com } \\
\text { temática ambiental }\end{array}$ & Objetivos Gerais & Ementa \\
\hline \multirow{2}{*}{$\begin{array}{l}\text { Ciências } \\
\text { Biológicas }\end{array}$} & $\begin{array}{l}\text { Educação Ambiental } \\
68 \mathrm{~h} \text { - Optativa }\end{array}$ & $\begin{array}{l}\text { (...) Educação Ambiental } \\
\text { (...) relações humanas e } \\
\text { socioambientais (...). }\end{array}$ & $\begin{array}{l}\text { (...) problemática } \\
\text { socioambiental (...) }\end{array}$ \\
\hline & $\begin{array}{l}\text { Formação de } \\
\text { Educadores } \\
\text { Ambientais } 102 \mathrm{~h}- \\
\text { Optativa } \\
\end{array}$ & $\begin{array}{l}\text { (...) Política Nacional de } \\
\text { Educação Ambiental; } \\
\text { (...) Plano Nacional de } \\
\text { Educação Ambiental. }\end{array}$ & $\begin{array}{l}\text { Educação Ambiental e } \\
\text { formação crítica de } \\
\text { educadores ambientais (...). }\end{array}$ \\
\hline $\begin{array}{l}\text { Educação } \\
\text { Física } \\
\text { (Diurno) }\end{array}$ & $\begin{array}{l}\text { Educação Física e } \\
\text { Meio Ambiente } 51 \mathrm{~h}- \\
\text { 1ํㅗ semestre }\end{array}$ & $\begin{array}{l}\text { (...) Educação } \\
\text { Ambiental, Meio } \\
\text { Ambiente, ecologia (...) } \\
\text { questões ambientais. }\end{array}$ & $\begin{array}{l}\text { (...) proposições ambientais } \\
\text { através da Educação Física } \\
\text { no ensino formal. }\end{array}$ \\
\hline \multirow{3}{*}{ Geografia } & $\begin{array}{l}\text { Antropologia } \\
\text { Ecológica II } 68 \mathrm{~h}-2^{\circ} \\
\text { semestre }\end{array}$ & $\begin{array}{l}\text { (...) distribuição dos } \\
\text { recursos naturais (...) } \\
\text { estudos de impactos } \\
\text { ambientais - EIA. }\end{array}$ & Sem termos relevantes. \\
\hline & $\begin{array}{l}\text { Biogeografia } 58 \mathrm{~h}- \\
3^{0} \text { semestre }\end{array}$ & $\begin{array}{l}\text { (...) conservação da } \\
\text { natureza e o } \\
\text { planejamento ambiental. }\end{array}$ & $\begin{array}{l}\text { (...) relações entre a } \\
\text { sociedade e a natureza no } \\
\text { mundo urbano e rural. } \\
\text { Diversidade ecológica e a } \\
\text { questão ambiental. }\end{array}$ \\
\hline & $\begin{array}{l}\text { Metodologia e } \\
\text { Prática do Ensino em } \\
\text { Geografia V: } \\
\text { Educação Ambiental } \\
68 \mathrm{~h}-6^{\circ} \text { semestre }\end{array}$ & $\begin{array}{l}\text { (...) trabalho da temática } \\
\text { ambiental nas escolas } \\
(\ldots) \text {. }\end{array}$ & $\begin{array}{l}\text { (...) Ensino da Geografia } \\
\text { Socioambiental (...). }\end{array}$ \\
\hline
\end{tabular}

Fonte: autoria própria.

É importante observar que os cursos de Ciências Biológicas e de Geografia possuem disciplinas que relacionam o ensino e a EA, fundamental para promover uma capacitação adequada ao futuro docente, no qual o profissional se torna apto a desenvolver projetos ou até mesmo inserir de temática ambiental na sua respectiva área de estudo de modo transversal. Já o curso de Educação Física apresenta uma disciplina logo no início da inserção do discente no curso, que relaciona diretamente a dimensão ambiental com a Educação Física, também exercendo papel fundamental na formação do profissional.

Em outro cenário, dos 53 cursos de Bacharelado, em 15 não foi encontrada temática ambiental dentre as disciplinas, que segue: Artes Visuais, Cinema de Animação, Cinema e Audiovisual, Enfermagem, Filosofia, Física, História, Letras (Tradução Português-Espanhol), Letras (Redação e Revisão de Textos), Letras (Tradução Inglês-Português), Medicina, Música, Odontologia, Psicologia e Violão. Os demais que apresentam abordagem ambiental em sua matriz curricular encontram-se tabelados no Quadro 2. 
Quadro 2: Cursos de Graduação nível Bacharelado e disciplinas com temática ambiental.

\begin{tabular}{|c|c|c|c|}
\hline Curso & $\begin{array}{c}\text { Disciplina com temática } \\
\text { ambiental }\end{array}$ & Objetivos Gerais & Ementa \\
\hline Administração & $\begin{array}{l}\text { Gestão Ambiental } 85 \mathrm{~h}- \\
6^{\circ} \text { semestre }\end{array}$ & $\begin{array}{l}\text { (...) Gestão ambiental } \\
\text { (...) impactos } \\
\text { ambientais. }\end{array}$ & $\begin{array}{l}\text { (...) Meio Ambiente. } \\
\text { Políticas Ambientais. } \\
\text { Gestão ambiental (...) }\end{array}$ \\
\hline Agronomia & \multicolumn{3}{|c|}{$\begin{array}{l}\text { Diversos (Ecologia } 68 \mathrm{~h}-1^{\circ} \text { semestre, Princípios de Agroecologia } 68 \mathrm{~h}-5^{\circ} \\
\text { sem., Manejo e Conservação do Solo } 68 \mathrm{~h}-8^{\circ} \text { sem., Gestão Ambiental } 51 \mathrm{~h}-8^{\circ} \\
\text { sem., entre outros). }\end{array}$} \\
\hline Antropologia & $\begin{array}{l}\text { Antropologia e Meio } \\
\text { Ambiente } 60 \mathrm{~h}-6^{\circ} \\
\text { semestre }\end{array}$ & $\begin{array}{l}\text { (...) relação } \\
\text { sociedade-natureza } \\
\text { (...) percepção e } \\
\text { apropriação da } \\
\text { natureza (...). }\end{array}$ & $\begin{array}{l}\text { (...) o campo ambiental, } \\
\text { suas problemáticas }(\ldots) \\
\text { problemática ambiental } \\
\text { (...). }\end{array}$ \\
\hline \multirow{4}{*}{$\begin{array}{l}\text { Arquitetura e } \\
\text { Urbanismo }\end{array}$} & $\begin{array}{l}\text { Estudos Sociais, } \\
\text { Econômicos e Ambientais } \\
34 \mathrm{~h}-3^{\circ} \text { semestre }\end{array}$ & $\begin{array}{l}\text { (...) entendimento dos } \\
\text { modos de ocupação e } \\
\text { configuração do } \\
\text { espaço urbano e do } \\
\text { meio ambiente (...). }\end{array}$ & Sem termos relevantes. \\
\hline & $\begin{array}{l}\text { Planejamento Regional } \\
102 \mathrm{~h}-4^{\circ} \text { semestre }\end{array}$ & $\begin{array}{l}\text { Sem termos } \\
\text { relevantes. }\end{array}$ & $\begin{array}{l}\text { (...) planejamento regional: } \\
\text { variáveis ambientais }(\ldots) \text {. }\end{array}$ \\
\hline & $\begin{array}{l}\text { Planejamento Urbano } \\
102 \mathrm{~h}-5^{\circ} \text { semestre }\end{array}$ & $\begin{array}{l}\text { (...) atividades de } \\
\text { planejamento urbano } \\
\text { incluindo fatores } \\
\text { ambientais }(. . .)\end{array}$ & $\begin{array}{l}\text { (...) integrando natureza, } \\
\text { espaço urbano e } \\
\text { sociedade. (...) } \\
\text { zoneamento ambiental } \\
\text { urbano (...) uso do solo. }\end{array}$ \\
\hline & $\begin{array}{l}\text { Atelier Vertical - } \\
\text { Sustentabilidade e } \\
\text { Soluções em Arquitetura } \\
102 \mathrm{~h}-\text { Optativa }\end{array}$ & $\begin{array}{l}\text { (...) arquitetura } \\
\text { sustentável. }\end{array}$ & $\begin{array}{l}\text { (...) sustentabilidade (...) } \\
\text { sustentabilidade e } \\
\text { eficiência energética nas } \\
\text { edificações }(\ldots) \text {. }\end{array}$ \\
\hline Biotecnologia & \multicolumn{3}{|c|}{$\begin{array}{l}\text { Diversas (Bioética } 51 \mathrm{~h}-2^{\circ} \text { semestre, Legislação em Biotecnologia } 34 \mathrm{~h}-6^{\circ} \\
\text { sem., Biotecnologia Ambiental } 34 \mathrm{~h}-6^{\circ} \text { sem., Biotecnologia aplicada ao } \\
\text { Agronegócio } 34 \mathrm{~h} \text { - Optativa, entre outros) }\end{array}$} \\
\hline \multirow[b]{2}{*}{$\begin{array}{l}\text { Ciência da } \\
\text { Computação }\end{array}$} & $\begin{array}{l}\text { Introdução à Ciência de } \\
\text { Computação } 68 \mathrm{~h}-10 \\
\text { semestre }\end{array}$ & $\begin{array}{l}\text { Sem termos } \\
\text { relevantes. }\end{array}$ & $\begin{array}{l}\text { (...) Relações da profissão } \\
\text { com a sociedade e o meio- } \\
\text { ambiente. }\end{array}$ \\
\hline & $\begin{array}{l}\text { Computação e Sociedade } \\
68 \mathrm{~h}-8^{\circ} \text { semestre }\end{array}$ & $\begin{array}{l}\text { (...) discutir aspectos } \\
\text { éticos e implicações } \\
\text { sociais e ambientais } \\
\text { da tecnologia (...). }\end{array}$ & $\begin{array}{l}\text { Impacto ambiental da } \\
\text { informática (...). Ética na } \\
\text { profissão, considerando as } \\
\text { questões de natureza } \\
\text { ambiental-ecológica (...). }\end{array}$ \\
\hline $\begin{array}{l}\text { Ciências } \\
\text { Sociais }\end{array}$ & $\begin{array}{l}\text { Sociologia IV } 68 \mathrm{~h}-4^{0} \\
\text { semestre }\end{array}$ & $\begin{array}{l}\text { Sem termos } \\
\text { relevantes. }\end{array}$ & Sem termos relevantes. \\
\hline $\begin{array}{l}\text { Design } \\
\text { Digital } \\
\end{array}$ & $\begin{array}{l}\text { Gestão do Design 34h - } \\
\text { Optativa }\end{array}$ & 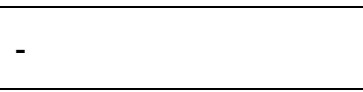 & $\begin{array}{l}\text { (...) Gestão e } \\
\text { sustentabilidade. }\end{array}$ \\
\hline \multirow{2}{*}{$\begin{array}{l}\text { Design } \\
\text { Gráfico }\end{array}$} & $\begin{array}{l}\text { Projeto de Embalagem } \\
68 \mathrm{~h}-5^{\circ} \text { semestre }\end{array}$ & - & $\begin{array}{l}\text { (...) Embalagem e meio } \\
\text { ambiente. (...) }\end{array}$ \\
\hline & $\begin{array}{l}\text { Gestão do Design 34h - } \\
\text { Optativa }\end{array}$ & - & $\begin{array}{l}\text { (...) Gestão e } \\
\text { sustentabilidade. }\end{array}$ \\
\hline Direito & $\begin{array}{l}\text { Direito Ambiental - } \\
\text { Optativa }\end{array}$ & - & $\begin{array}{l}\text { (...) Direito Ambiental (...) } \\
\text { (...). Desenvolvimento } \\
\text { Sustentável. }\end{array}$ \\
\hline
\end{tabular}

Continua... 
...continuação

\begin{tabular}{|c|c|c|c|}
\hline Curso & $\begin{array}{c}\text { Disciplina com temática } \\
\text { ambiental }\end{array}$ & Objetivos Gerais & Ementa \\
\hline $\begin{array}{l}\text { Educação } \\
\text { Física }\end{array}$ & $\begin{array}{l}\text { Atividades Físicas de } \\
\text { Ação na Natureza } 51 \mathrm{~h}- \\
2^{\circ} \text { semestre }\end{array}$ & $\begin{array}{l}\text { (...) atividades físicas } \\
\text { no meio ambiente } \\
\text { natural (...) } \\
\text { preservação do meio } \\
\text { ambiente (...). }\end{array}$ & $\begin{array}{l}\text { Atividades Físicas (...). } \\
\text { Natureza e suas relações } \\
\text { com o meio ambiente (...). } \\
\text { Esportes na Natureza. }\end{array}$ \\
\hline $\begin{array}{l}\text { Engenharia } \\
\text { Agrícola }\end{array}$ & \multicolumn{3}{|c|}{ 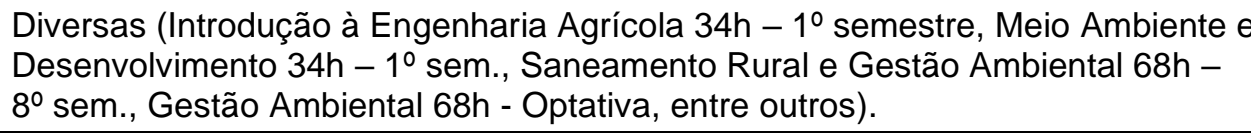 } \\
\hline \multirow{2}{*}{$\begin{array}{l}\text { Engenharia } \\
\text { Ambiental e } \\
\text { Sanitária }\end{array}$} & \multicolumn{3}{|c|}{$\begin{array}{l}\text { Diversas (Gestão Ambiental 34h - 8o sem., Gerenciamento e Tratamento de } \\
\text { Resíduos Sólidos } 68 \mathrm{~h}-7^{\circ} \text { sem., Recuperação de Áreas Degradadas } 68 \mathrm{~h}-9 \text { - } \\
\text { sem., Esgotamento Sanitário } 68 \mathrm{~h}-9^{\circ} \text { sem., entre outros). }\end{array}$} \\
\hline & $\begin{array}{l}\text { Educação Ambiental } 68 \mathrm{~h} \\
-4^{\circ} \text { semestre }\end{array}$ & $\begin{array}{l}\text { (...) Educação } \\
\text { Ambiental no âmbito } \\
\text { do saneamento } \\
\text { ambiental. }\end{array}$ & $\begin{array}{l}\text { Fundamentos (...) e } \\
\text { trajetória da Educação } \\
\text { Ambiental (...). Projetos de } \\
\text { Educação Ambiental. }\end{array}$ \\
\hline \multirow{2}{*}{$\begin{array}{l}\text { Engenharia } \\
\text { Civil }\end{array}$} & $\begin{array}{l}\text { Engenharia Civil e } \\
\text { Qualidade Ambiental } 34 \mathrm{~h} \\
\text { - 1을 semestre }\end{array}$ & $\begin{array}{l}\text { (...) qualidade } \\
\text { ambiental. }\end{array}$ & $\begin{array}{l}\text { (...) Saneamento. (...) } \\
\text { Aproveitamento de } \\
\text { Resíduos da Indústria. (...) } \\
\text { Qualidade Ambiental (...). } \\
\text { Licenciamento Ambiental }\end{array}$ \\
\hline & $\begin{array}{l}\text { Diagnóstico e Controle de } \\
\text { Impactos Ambientais } 34 \mathrm{~h} \\
\text { - 9ㅇs semestre }\end{array}$ & $\begin{array}{l}\text { (...) impactos } \\
\text { ambientais gerados } \\
\text { pelas atividades } \\
\text { humanas (...) } \\
\text { licenciamento } \\
\text { ambiental (...). } \\
\end{array}$ & $\begin{array}{l}\text { Legislação ambiental } \\
\text { brasileira. (...) impactos } \\
\text { ambientais (...) }\end{array}$ \\
\hline \multirow{4}{*}{$\begin{array}{l}\text { Engenharia } \\
\text { da } \\
\text { Computação }\end{array}$} & $\begin{array}{l}\text { Introdução à Engenharia } \\
\text { de Computação } 68 \mathrm{~h}-1 \stackrel{0}{ } \\
\text { semestre }\end{array}$ & $\begin{array}{l}\text { Sem termos } \\
\text { relevantes. }\end{array}$ & $\begin{array}{l}\text { (...) Relações da profissão } \\
\text { com a sociedade e o meio- } \\
\text { ambiente. }\end{array}$ \\
\hline & $\begin{array}{l}\text { Computação e Sociedade } \\
68 \mathrm{~h}-6^{\circ} \text { semestre }\end{array}$ & $\begin{array}{l}\text { (...) discutir aspectos } \\
\text { éticos e implicações } \\
\text { sociais e ambientais } \\
\text { da tecnologia (...). }\end{array}$ & $\begin{array}{l}\text { Impacto social e ambiental } \\
\text { da informática (...). Ética } \\
\text { na profissão, considerando } \\
\text { as questões de natureza } \\
\text { ambiental-ecológica. }\end{array}$ \\
\hline & $\begin{array}{l}\text { Eletrônica Básica I } 68 \mathrm{~h} \text { - } \\
\text { 5o semestre }\end{array}$ & $\begin{array}{l}\text { Sem termos } \\
\text { relevantes. }\end{array}$ & $\begin{array}{l}\text { (...) Descarte de resíduos } \\
\text { eletrônicos. }\end{array}$ \\
\hline & $\begin{array}{l}\text { Eletrônica Básica II 68h - } \\
\text { 7ํ semestre }\end{array}$ & $\begin{array}{l}\text { Sem termos } \\
\text { relevantes. }\end{array}$ & $\begin{array}{l}\text { (...) Gerenciamento de } \\
\text { resíduos eletrônicos. }\end{array}$ \\
\hline $\begin{array}{l}\text { Engenharia } \\
\text { de Controle e } \\
\text { Automação }\end{array}$ & $\begin{array}{l}\text { Meio Ambiente e } \\
\text { Desenvolvimento } 34 \mathrm{~h}- \\
10^{\circ} \text { semestre }\end{array}$ & $\begin{array}{l}\text { (...) meio ambiente e } \\
\text { desenvolvimento }(. . .) \text {. }\end{array}$ & $\begin{array}{l}\text { Meio ambiente (...). A } \\
\text { questão ambiental (...). } \\
\text { Desenvolvimento } \\
\text { sustentável (...) }\end{array}$ \\
\hline $\begin{array}{l}\text { Engenharia } \\
\text { de Materiais }\end{array}$ & $\begin{array}{l}\text { Ecologia e Impacto } \\
\text { Ambiental } 34 \mathrm{~h}-3^{\circ} \\
\text { semestre }\end{array}$ & $\begin{array}{l}\text { (...) ecologia e } \\
\text { manejo de recursos } \\
\text { naturais (...) } \\
\text { conservação da } \\
\text { biodiversidade. }\end{array}$ & $\begin{array}{l}\text { Ecologia (...) equilíbrio } \\
\text { ecológico (...). } \\
\text { Preservação de recursos } \\
\text { naturais. }\end{array}$ \\
\hline
\end{tabular}

Continua... 


\begin{tabular}{|c|c|c|c|}
\hline Curso & $\begin{array}{c}\text { Disciplina com temática } \\
\text { ambiental }\end{array}$ & Objetivos Gerais & Ementa \\
\hline $\begin{array}{l}\text { Engenharia } \\
\text { de Petróleo }\end{array}$ & $\begin{array}{l}\text { Avaliação dos Impactos } \\
\text { Ambientais no Setor de } \\
\text { Petróleo } 68 \mathrm{~h}-8^{\circ} \\
\text { semestre }\end{array}$ & $\begin{array}{l}\text { (...) avaliação de } \\
\text { impactos ambientais } \\
(\ldots) \text {. }\end{array}$ & $\begin{array}{l}\text { Diagnóstico ambiental (...). } \\
\text { Impactos Ambientais (...). } \\
\text { Sistemas de } \\
\text { Gerenciamento Ambiental. }\end{array}$ \\
\hline $\begin{array}{l}\text { Engenharia } \\
\text { de Produção }\end{array}$ & $\begin{array}{l}\text { Engenharia Ambiental } 68 \mathrm{~h} \\
-9^{\circ} \text { semestre }\end{array}$ & $\begin{array}{l}\text { (...) problemática } \\
\text { social e ambiental } \\
\text { nas empresas (...). }\end{array}$ & $\begin{array}{l}\text { (...) gestão ambiental (...). } \\
\text { Economia e Meio } \\
\text { ambiente. Estudos de } \\
\text { impacto ambiental (...). }\end{array}$ \\
\hline $\begin{array}{l}\text { Engenharia } \\
\text { Eletrônica }\end{array}$ & $\begin{array}{l}\text { Meio Ambiente e } \\
\text { Desenvolvimento } 34 \mathrm{~h}- \\
10^{\circ} \text { semestre }\end{array}$ & $\begin{array}{l}\text { (...) meio ambiente e } \\
\text { desenvolvimento. }\end{array}$ & $\begin{array}{l}\text { Meio ambiente (...). A } \\
\text { questão ambiental (...). } \\
\text { Desenvolvimento } \\
\text { sustentável (...) }\end{array}$ \\
\hline \multirow{2}{*}{$\begin{array}{l}\text { Engenharia } \\
\text { Geológica }\end{array}$} & $\begin{array}{l}\text { Geologia Geral } 68 \mathrm{~h}-10 \\
\text { semestre }\end{array}$ & $\begin{array}{l}\text { Sem termos } \\
\text { relevantes. }\end{array}$ & $\begin{array}{l}\text { (...) Geologia e o meio } \\
\text { ambiente. (...) Poluição e } \\
\text { impactos ambientais. } \\
\text { Sustentabilidade (...) }\end{array}$ \\
\hline & $\begin{array}{l}\text { Hidrogeologia I } 102 \mathrm{~h}-7^{0} \\
\text { semestre }\end{array}$ & $\begin{array}{l}\text { Sem termos } \\
\text { relevantes. }\end{array}$ & $\begin{array}{l}\text { (...) Aproveitamento } \\
\text { sustentável da água (...). } \\
\text { Caracterização de fontes } \\
\text { de poluição de água (...). }\end{array}$ \\
\hline $\begin{array}{l}\text { Engenharia } \\
\text { Hídrica }\end{array}$ & \multicolumn{3}{|c|}{$\begin{array}{l}\text { Diversas (Ecologia e Impacto Ambiental } 34 \mathrm{~h}-2^{\circ} \text { semestre, Cidadania, Ética e } \\
\text { Responsabilidade Social } 34 \mathrm{~h}-3^{\circ} \text { sem., Direito Ambiental e dos Recursos } \\
\text { Hídricos } 34 \mathrm{~h}-6^{\circ} \text { sem., Energia e Meio Ambiente - Optativa, entre outros). }\end{array}$} \\
\hline \multirow{3}{*}{$\begin{array}{l}\text { Engenharia } \\
\text { Industrial } \\
\text { Madeireira }\end{array}$} & $\begin{array}{l}\text { Meio Ambiente e } \\
\text { Desenvolvimento } 34 \mathrm{~h}-1^{\circ} \\
\text { semestre }\end{array}$ & $\begin{array}{l}\text { (...) meio ambiente e } \\
\text { desenvolvimento. }\end{array}$ & $\begin{array}{l}\text { Meio ambiente (...). A } \\
\text { questão ambiental (...). } \\
\text { Desenvolvimento } \\
\text { sustentável (...) }\end{array}$ \\
\hline & $\begin{array}{l}\text { Resíduos na Indústria de } \\
\text { Base Madeireira } 68 \mathrm{~h}-7^{0} \\
\text { semestre }\end{array}$ & $\begin{array}{l}\text { (...) resíduos, } \\
\text { líquidos, sólidos e } \\
\text { gasosos (...) relações } \\
\text { com o ambiente. }\end{array}$ & $\begin{array}{l}\text { Ecossistemas e } \\
\text { desenvolvimento } \\
\text { sustentável (...). } \\
\text { Legislação ambiental (...) }\end{array}$ \\
\hline & $\begin{array}{l}\text { Sistema de Gestão } \\
\text { Ambiental } 68 \mathrm{~h}-8^{\circ} \\
\text { semestre }\end{array}$ & $\begin{array}{l}\text { (...) gestão ambiental } \\
\text { no âmbito } \\
\text { empresarial (...). }\end{array}$ & $\begin{array}{l}\text { Gestão Ambiental (...). } \\
\text { Licenciamento Ambiental. } \\
\text { Avaliação do Impacto } \\
\text { Ambiental (...). }\end{array}$ \\
\hline Farmácia & \multicolumn{3}{|c|}{$\begin{array}{l}\text { Diversas (Biossegurança em Laboratórios 34h - Optativa, Química Geral } 68 \mathrm{~h} \text { - } \\
\text { 1ํ semestre, Bioquímica I 102h - 3ำ sem., Tecnologias Limpas } 34 \mathrm{~h} \text { - Optativa, } \\
\text { entre outras). }\end{array}$} \\
\hline \multirow[b]{2}{*}{ Geografia } & $\begin{array}{l}\text { Geografia Rural } 68 \mathrm{~h}-4^{0} \\
\text { semestre }\end{array}$ & $\begin{array}{l}\text { (...) integração com } \\
\text { meio ecológico; }\end{array}$ & (...) ambiente natural (...) \\
\hline & $\begin{array}{l}\text { Gestão de Recursos } \\
\text { Naturais e Legislação } \\
\text { Ambiental } 68 \mathrm{~h}-5^{\circ} \\
\text { semestre }\end{array}$ & $\begin{array}{l}\text { (...) gestão adequada } \\
\text { dos recursos naturais } \\
\text { (...) legislação } \\
\text { ambiental (...). }\end{array}$ & $\begin{array}{l}\text { Gestão de recursos } \\
\text { naturais e } \\
\text { desenvolvimento } \\
\text { sustentável (...). Avaliação } \\
\text { de impactos ambientais } \\
\text { (...). Legislação ambiental. }\end{array}$ \\
\hline
\end{tabular}

Continua... 
...continuação.

\begin{tabular}{|c|c|c|c|}
\hline Curso & $\begin{array}{c}\text { Disciplina com temática } \\
\text { ambiental }\end{array}$ & Objetivos Gerais & Ementa \\
\hline \multirow[b]{2}{*}{ Geografia } & $\begin{array}{l}\text { ElA - RIMA: Estudo de } \\
\text { Impacto Ambiental e } \\
\text { Relatório de Impacto } \\
\text { Ambiental } 34 \mathrm{~h}-6^{\circ} \\
\text { semestre }\end{array}$ & $\begin{array}{l}\text { (...) estudos } \\
\text { ambientais (...) }\end{array}$ & $\begin{array}{l}\text { (...) diagnóstico ambiental } \\
(\ldots)\end{array}$ \\
\hline & $\begin{array}{l}\text { Planejamento Ambiental } \\
68 \mathrm{~h}-7^{\circ} \text { semestre }\end{array}$ & $\begin{array}{l}\text { (...) gestão, } \\
\text { planejamento e } \\
\text { manejo dos recursos } \\
\text { naturais (...) susten- } \\
\text { tabilidade (...) questão } \\
\text { socioambiental. }\end{array}$ & $\begin{array}{l}\text { (...) planejamento } \\
\text { socioambiental (...). } \\
\text { Educação Ambiental (...) }\end{array}$ \\
\hline Jornalismo & $\begin{array}{l}\text { Jornalismo Ambiental } 68 \mathrm{~h} \\
-4^{\circ} \text { semestre }\end{array}$ & $\begin{array}{l}\text { (...) desenvolvimento } \\
\text { sustentável. }\end{array}$ & $\begin{array}{l}\text { (...) desenvolvimento } \\
\text { sustentável e a economia } \\
\text { verde (...) práticas } \\
\text { sustentáveis }(. . .) .\end{array}$ \\
\hline $\begin{array}{l}\text { Medicina } \\
\text { Veterinária }\end{array}$ & $\begin{array}{l}\text { Zoonose e Administração } \\
\text { Sanitária em Saúde } \\
\text { Pública } 68 \mathrm{~h}-9^{\circ} \text { semestre }\end{array}$ & - & $\begin{array}{l}\text { (...) interação ecológica } \\
\text { (...) defesa do meio } \\
\text { ambiente }(. . .)\end{array}$ \\
\hline \multirow[b]{2}{*}{ Meteorologia } & $\begin{array}{l}\text { Ecologia } 51 \mathrm{~h}-1^{\circ} \\
\text { semestre }\end{array}$ & $\begin{array}{l}\text { (...) ecologia }(. . .) \\
\text { questões ambientais } \\
\text { atuais. }\end{array}$ & $\begin{array}{l}\text { (...) principais questões } \\
\text { ambientais atuais (...) mu- } \\
\text { dança climática global (...). }\end{array}$ \\
\hline & $\begin{array}{l}\text { Introdução à Química e } \\
\text { Poluição Atmosféricas } \\
68 \text { - 8osemestre }\end{array}$ & $\begin{array}{l}\text { (...) medição e } \\
\text { monitoramento (...) e } \\
\text { do controle da } \\
\text { poluição atmosférica. }\end{array}$ & $\begin{array}{l}\text { (...) Poluição do Ar (...). } \\
\text { Processos de Remoção } \\
\text { de Poluentes Atmosféricos } \\
\text { (...). Controle da Poluição } \\
\text { Atmosférica. }\end{array}$ \\
\hline \multirow[t]{2}{*}{ Museologia } & $\begin{array}{l}\text { Botânica } 51 \mathrm{~h}-3^{\circ} \\
\text { semestre }\end{array}$ & $\begin{array}{l}\text { (...) biodiversidade (...) } \\
\text { preservação de } \\
\text { plantas em herbários } \\
(\ldots) .\end{array}$ & $\begin{array}{l}\text { (...) Biodiversidade. } \\
\text { Métodos e técnicas de } \\
\text { preservação de plantas } \\
\text { em herbários (...). }\end{array}$ \\
\hline & Ecologia - Optativa & $\begin{array}{l}\text { Não encontrado no } \\
\text { PPC }\end{array}$ & Não encontrado no PPC \\
\hline Nutrição & $\begin{array}{l}\text { Ecologia e Saneamento } \\
\text { Ambiental } 34 \mathrm{~h}-3^{\circ} \\
\text { semestre }\end{array}$ & 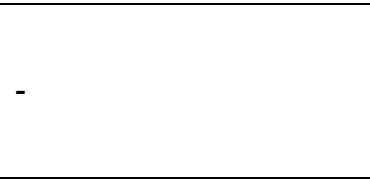 & $\begin{array}{l}\text { (...) ECOLOGIA (...) } \\
\text { fatores ecológicos, } \\
\text { climáticos, abióticos, (...) } \\
\text { saneamento ambiental. }\end{array}$ \\
\hline \multirow{2}{*}{ Química } & $\begin{array}{l}\text { Química Ambiental I } 51 \mathrm{~h} \\
-7^{\circ} \text { semestre }\end{array}$ & $(\ldots)$ resíduos $(\ldots)$ & $\begin{array}{l}\text { (...) Energia e meio } \\
\text { ambiente (...). Fatores } \\
\text { naturais de poluição do ar } \\
\text { (...). Poluição ambiental } \\
\text { (...). Legislação Ambiental }\end{array}$ \\
\hline & $\begin{array}{l}\text { Química Ambiental II } 51 \mathrm{~h} \\
-8^{\circ} \text { semestre }\end{array}$ & $\begin{array}{l}\text { (...) Qualidade e } \\
\text { Poluição da água, } \\
\text { tratamento de águas } \\
\text { residuais e de esgotos } \\
\text { (...) meio ambiente. }\end{array}$ & $\begin{array}{l}\text { (...) Tratamento de águas } \\
\text { residuais e de esgoto. } \\
\text { Gerenciamento de } \\
\text { resíduos e solos } \\
\text { contaminados (...). }\end{array}$ \\
\hline
\end{tabular}

Continua... 
...continuação.

\begin{tabular}{|c|c|c|c|}
\hline Curso & $\begin{array}{c}\text { Disciplina com temática } \\
\text { ambiental }\end{array}$ & Objetivos Gerais & Ementa \\
\hline $\begin{array}{l}\text { Química de } \\
\text { Alimentos }\end{array}$ & $\begin{array}{l}\text { Tratamento de Água e } \\
\text { Resíduos na Indústria de } \\
\text { Alimentos } 68 \mathrm{~h}-2^{\circ} \\
\text { semestre }\end{array}$ & $\begin{array}{l}\text { (...) tratamento de } \\
\text { águas e resíduos } \\
\text { industriais. }\end{array}$ & $\begin{array}{l}\text { (...) tratamento de } \\
\text { efluentes (...) poluição } \\
\text { hídrica (...). Resíduos } \\
\text { sólidos (...). Legislação } \\
\text { ambiental. }\end{array}$ \\
\hline $\begin{array}{l}\text { Química } \\
\text { Forense }\end{array}$ & $\begin{array}{l}\text { Toxicologia II } 68 \mathrm{~h}-6^{\circ} \\
\text { semestre }\end{array}$ & $\begin{array}{l}\text { (...) toxicologia } \\
\text { ambiental; (...). }\end{array}$ & $\begin{array}{l}\text { (...) Toxicologia ambiental } \\
(\ldots)\end{array}$ \\
\hline \multirow{3}{*}{$\begin{array}{l}\text { Química } \\
\text { Industrial }\end{array}$} & $\begin{array}{l}\text { Química Ambiental } 51 \mathrm{~h}- \\
\text { 60 semestre }\end{array}$ & $\begin{array}{l}\text { (...) ponto de vista } \\
\text { ambiental. }\end{array}$ & $\begin{array}{l}\text { (...) Química Ambiental } \\
\text { (...). Gerenciamento de } \\
\text { resíduos e solos contami- } \\
\text { nados; Poluição ambiental } \\
\text { (...). Legislação Ambiental. }\end{array}$ \\
\hline & $\begin{array}{l}\text { Química Verde } 34 \mathrm{~h}-5^{\circ} \\
\text { semestre }\end{array}$ & (...) Química Verde (...) & (...) Química Verde (...) \\
\hline & $\begin{array}{l}\text { Tratamento de Água e } \\
\text { Resíduos Industriais } 51 \mathrm{~h} \\
-7^{\circ} \text { semestre }\end{array}$ & $\begin{array}{l}\text { (...) tratamento de } \\
\text { água e resíduos } \\
\text { industriais }(. . .) \text {. }\end{array}$ & $\begin{array}{l}\text { (...) Tratamento de águas } \\
\text { residuais e industriais (...) } \\
\text { tratamento de efluentes } \\
\text { (...) poluição hídrica (...). } \\
\text { Resíduos sólidos. } \\
\text { Legislação ambiental. }\end{array}$ \\
\hline $\begin{array}{l}\text { Relações } \\
\text { Internacionais }\end{array}$ & $\begin{array}{l}\text { Meio Ambiente e RI 68h } \\
\text { - Optativa }\end{array}$ & $\begin{array}{l}\text { (...) impacto dos } \\
\text { processos ambientais } \\
(\ldots)\end{array}$ & $\begin{array}{l}\text { (...) conflitos ecológicos (...) } \\
\text { ecologismo contemporâneo } \\
(\ldots) \text {. }\end{array}$ \\
\hline $\begin{array}{l}\text { Terapia } \\
\text { Ocupacional }\end{array}$ & $\begin{array}{l}\text { Recursos Terapêuticos } \\
V \text { - Atividade terapêutica } \\
\text { na natureza } 51 \mathrm{~h}- \\
\text { Optativa }\end{array}$ & $\begin{array}{l}\text { (...) atividades terapêu- } \\
\text { ticas no meio ambiente } \\
\text { natural (...) preservação } \\
\text { do meio ambiente (...). }\end{array}$ & $\begin{array}{l}\text { (...) relações com o meio } \\
\text { ambiente }(. . .) \text { ecoturismo } \\
\text { (...). Esportes na Natureza. }\end{array}$ \\
\hline \multirow[t]{2}{*}{ Turismo } & $\begin{array}{l}\text { Turismo e Meio } \\
\text { Ambiente } 68 \mathrm{~h}-5^{\circ} \\
\text { semestre }\end{array}$ & $\begin{array}{l}\text { (...) turismo e meio } \\
\text { ambiente }(. . .) \\
\text { sustentabilidade e da } \\
\text { responsabilidade } \\
\text { socioambiental (...). }\end{array}$ & $\begin{array}{l}\text { Meio ambiente (...) ecologia } \\
\text { (...). Políticas públicas } \\
\text { ambientais e o turismo (...). } \\
\text { Sustentabilidade no } \\
\text { turismo. Responsabilidade } \\
\text { socioambiental (...) }\end{array}$ \\
\hline & $\begin{array}{l}\text { Gestão Ambiental no } \\
\text { Turismo 68h - Optativo }\end{array}$ & $\begin{array}{l}\text { (...) gestão ambiental no } \\
\text { turismo (...). }\end{array}$ & $\begin{array}{l}\text { (...) questão ambiental (...) } \\
\text { sustentabilidade (...). } \\
\text { Responsabilidade } \\
\text { socioambiental (..) } \\
\text { Educação Ambiental (...). }\end{array}$ \\
\hline \multirow[b]{2}{*}{ Zootecnia } & $\begin{array}{l}\text { Ecologia Básica e } \\
\text { Gestão Ambiental } 51 \mathrm{~h}- \\
\text { 1ํ semestre }\end{array}$ & $\begin{array}{l}\text { (...) equilíbrio da } \\
\text { natureza (...) utilização } \\
\text { racional dos recursos } \\
\text { naturais renováveis. }\end{array}$ & $\begin{array}{l}\text { (...) ecologia (...) poluição; } \\
\text { conservação de recursos } \\
\text { naturais renováveis. }\end{array}$ \\
\hline & $\begin{array}{l}\text { Gestão Ambiental dos } \\
\text { Resíduos Orgânicos ge- } \\
\text { rados nos Sistemas de } \\
\text { Produção Agropecuário } \\
68 \mathrm{~h} \text { - Optativa }\end{array}$ & $\begin{array}{l}\text { (...) resíduos orgânicos } \\
\text { (...) impacto ambiental } \\
\text { (...). }\end{array}$ & $\begin{array}{l}\text { Meio ambiente, sustentabi- } \\
\text { lidade, (...) Impacto } \\
\text { ambiental causado pela } \\
\text { produção agropecuária nos } \\
\text { ecossistemas. }\end{array}$ \\
\hline
\end{tabular}

Fonte: autoria própria.

Revbea, São Paulo, V. 15, № 3: 53-72, 2020. 
Em relação ao curso de Ciências Sociais, pode-se observar no Quadro 2 que a disciplina de Sociologia IV não apresenta termos relevantes à temática ambiental nem em seus Objetivos ou sua Ementa. Entretanto, quando discorrido sobre a PNEA no PPC, é apontado o seguinte:

A questão da Educação Ambiental será tratada na Sociologia IV, ao trazer as discussões de autores com Giddens e Beck sobre a sociedade de Risco e modernidade reflexiva. Outro autor que debaterá a questão ambiental como forma de demonstrar a crise do projeto cultural da modernidade será Boaventura de Souza Santos.

Nos demais cursos pode-se observar a vasta presença de termos que retomam a discussão de desenvolvimento sustentável, gestão ambiental ou de recursos naturais, licenciamento ambiental, legislação ambiental e prevenção ou remediação de impactos ambientais causados pela área de estudo (como tratamento de efluentes e de resíduos e estudos sobre poluição hídrica). Além disso, ressalta-se a presença de disciplinas sobre EA nos cursos de Engenharia Ambiental e Sanitária e Gestão Ambiental.

Deve-se ressaltar a ausência de disciplinas voltadas à discussão ambiental nas matrizes curriculares de Enfermagem, Medicina e Odontologia, cursos voltados à área da saúde. É importante apontar a incidência de Resíduos de Serviço de Saúde (RSS) no exercício dessas profissões, os quais podem ser de origem comum, semelhante aos resíduos domésticos, ou de origem biológica, química, radioativa ou perfurocortante, oferecendo riscos potenciais ao meio ambiente e saúde pública. Deste modo, é fundamental a instrução de geradores de RSS quanto o gerenciamento adequado desses resíduos, principalmente no que tange as fases de manejo (segregação, acondicionamento, armazenamento, coleta, transporte, tratamento e disposição final) devido aos riscos que podem oferecer (BRASIL, 2006).

No que se refere aos cursos de grau Tecnológico, todos apresentaram disciplinas com temática ambiental em suas respectivas matrizes curriculares, os quais encontram-se tabulados no Quadro 3 (próxima página).

Assim como nos cursos de Bacharelado, nota-se principalmente a presença de termos voltados à sustentabilidade, licenciamento e gestão ambiental. O estudo desses temas, assim como problemáticas atuais no cenário ambiental preparam o profissional para sua futura atuação no mercado, de modo a viabilizar adesão às atitudes ambientalmente responsáveis, de acordo com o conteúdo incorporado ao longo de sua formação (SILVA et al., 2012). Deve-se apontar a presença de uma disciplina voltada a EA no curso de Gestão Ambiental. 
Quadro 3: Cursos de Graduação nível Tecnológico e disciplinas com temática ambiental.

\begin{tabular}{|c|c|c|c|}
\hline Curso & $\begin{array}{c}\text { Disciplina com } \\
\text { temática ambiental }\end{array}$ & Objetivos Gerais & Ementa \\
\hline Alimentos & $\begin{array}{l}\text { Ciência Ambiental } \\
\text { aplicada à Tec. } \\
\text { Alimentos } 60 \mathrm{~h}-2^{\circ} \\
\text { semestre }\end{array}$ & $\begin{array}{l}\text { Conhecer a } \\
\text { tecnologia do } \\
\text { tratamento de } \\
\text { águas e resíduos } \\
\text { industriais. }\end{array}$ & $\begin{array}{l}\text { (...) tratamento de } \\
\text { efluentes na } \\
\text { agroindústria alimentar; } \\
\text { Poluição da } \\
\text { agroindústria alimentar: } \\
\text { (...) desenvolvimento } \\
\text { Sustentável;(..) } \\
\text { Legislação ambiental; } \\
\text { (...) Tratamento de } \\
\text { resíduos sólidos; (...) }\end{array}$ \\
\hline Gastronomia & $\begin{array}{l}\text { Etica, Sustentabilidade e } \\
\text { Meio Ambiente } 34 \mathrm{~h}-4^{\circ} \\
\text { semestre }\end{array}$ & $\begin{array}{l}\text { (...) meio ambiente } \\
\text { e o } \\
\text { desenvolvimento } \\
\text { sustentável. }\end{array}$ & $\begin{array}{l}\text { (...) impacto da atuação } \\
\text { do homem sobre o meio } \\
\text { ambiente (...) } \\
\text { sustentabilidade (...). }\end{array}$ \\
\hline \multirow[t]{2}{*}{ Geoprocessamento } & \begin{tabular}{|l} 
Meio Ambiente e \\
Desenvolvimento $34 \mathrm{~h}-$ \\
$6^{\circ}$ semestre \\
\end{tabular} & $\begin{array}{l}\text { (...) meio ambiente } \\
\text { e desenvolvimento. }\end{array}$ & $\begin{array}{l}\text { Meio ambiente (...) A } \\
\text { questão ambiental (...) } \\
\text { Desenvolvimento } \\
\text { sustentável (...) }\end{array}$ \\
\hline & $\begin{array}{l}\text { Licenciamento Ambiental } \\
68 \mathrm{~h} \text { - Optativa }\end{array}$ & $\begin{array}{l}\text { (...) licenciamento } \\
\text { ambiental }(\ldots)\end{array}$ & $\begin{array}{l}\text { Licenciamento ambiental } \\
\text { como instrumento de } \\
\text { Política Ambiental (...) }\end{array}$ \\
\hline \multirow[b]{2}{*}{ Gestão Ambiental } & \multicolumn{3}{|c|}{$\begin{array}{l}\text { Diversas (Inovação e Sustentabilidade } 68 \mathrm{~h}-2^{\circ} \text { semestre; Indicadores de } \\
\text { Qualidade Ambiental } 68 \mathrm{~h}-3^{\circ} \text { sem.; Economia do Meio Ambiente } 68 \mathrm{~h}-3^{\circ} \\
\text { sem.; Legislação Ambiental } 68 \mathrm{~h}-3^{\circ} \text { sem.; entre outros) }\end{array}$} \\
\hline & $\begin{array}{l}\text { Fundamentos de } \\
\text { Educação Ambiental } 68 \mathrm{~h} \\
-1^{\circ} \text { semestre }\end{array}$ & $\begin{array}{l}\text { (...) Educação } \\
\text { Ambiental }\end{array}$ & $\begin{array}{l}\text { Crise ambiental (...) } \\
\text { Educação Ambiental } \\
\text { (...). Política Nacional de } \\
\text { Educação Ambiental } \\
\text { (...). }\end{array}$ \\
\hline Gestão Pública & $\begin{array}{l}\text { Gestão Ambiental e } \\
\text { Sustentabilidade } 68 \mathrm{~h}- \\
\text { Optativa }\end{array}$ & - & $\begin{array}{l}\text { (...) desenvolvimento } \\
\text { sustentável. Impactos e } \\
\text { aspectos ambientais. } \\
\text { Gestão Ambiental (...) }\end{array}$ \\
\hline Hotelaria & $\begin{array}{l}\text { Gestão da Ética e } \\
\text { Responsabilidade } \\
\text { Socioambiental em } \\
\text { Empresas Hoteleiras e } \\
\text { Extra-hoteleiras } 68 \mathrm{~h}-1 \text { 으 } \\
\text { semestre }\end{array}$ & $\begin{array}{l}\text { (...) preservação do } \\
\text { meio ambiente (...) } \\
\text { dimensão } \\
\text { ambiental (...) } \\
\text { medidas } \\
\text { preventivas de } \\
\text { geração de } \\
\text { resíduos (...) } \\
\text { aspectos e } \\
\text { impactos } \\
\text { ambientais (...) } \\
\text { sistemas de gestão } \\
\text { ambiental (...) }\end{array}$ & $\begin{array}{l}\text { A dimensão ambiental } \\
\text { (...) impactos ambientais } \\
\text { relacionados ao turismo } \\
\text { e hotelaria. Legislação } \\
\text { ambiental. (...) } \\
\text { Desenvolvimento } \\
\text { Sustentável. (...) gestão } \\
\text { ambiental (...) geração } \\
\text { de resíduos, de } \\
\text { consumo de energia e } \\
\text { de água (...) Educação } \\
\text { Ambiental, ética e } \\
\text { responsabilidade } \\
\text { socioambiental. }\end{array}$ \\
\hline
\end{tabular}

Fonte: autoria própria.

Revbea, São Paulo, V. 15, № 3: 53-72, 2020. 
Por fim, em relação aos PPG, que estão distribuídos entre Mestrado Acadêmico e Doutorado, os cursos que não apresentam disciplinas com abordagem ambiental são: Física (Doutorado), Fisiologia Vegetal (Doutorado), Letras, Nutrição e Alimentos (Mestrado Acadêmico). Os demais PPG e suas respectivas disciplinas apresentam-se tabulados no Quadro 4.

Quadro 4: Programas de Pós-Graduação e disciplinas com temática ambiental.

\begin{tabular}{|c|c|c|}
\hline Curso - Grau & $\begin{array}{l}\text { Disciplina com temática } \\
\text { ambiental }\end{array}$ & Ementa \\
\hline $\begin{array}{l}\text { Artes Visuais - } \\
\text { Mestrado Acadêmico }\end{array}$ & $\begin{array}{l}\text { Gravura e Impressão: } \\
\text { inovação e tradição }\end{array}$ & $\begin{array}{l}\text { (...) A sustentabilidade e as } \\
\text { inovações tecnológicas dentro da } \\
\text { área da gravura artística. }\end{array}$ \\
\hline $\begin{array}{l}\text { Ciência e Tecnologia } \\
\text { de Alimentos - } \\
\text { Mestrado Acadêmico }\end{array}$ & Química Verde e Sustentável & Química Verde (...) \\
\hline \multirow{2}{*}{$\begin{array}{l}\text { Ciências Ambientais - } \\
\text { Mestrado Acadêmico }\end{array}$} & \multicolumn{2}{|c|}{$\begin{array}{l}\text { Diversas (Avaliação de Impactos Ambientais 68h, Planejamento e } \\
\text { Gestão Ambiental 68h, Perícia Ambiental 34h, entre outras) }\end{array}$} \\
\hline & $\begin{array}{l}\text { Educação Sanitária e } \\
\text { Ambiental } 51 \mathrm{~h}\end{array}$ & $\begin{array}{l}\text { Crise ambiental. (...) Educação } \\
\text { Ambiental. (...). Sustentabilidade. }\end{array}$ \\
\hline $\begin{array}{l}\text { Geografia - Mestrado } \\
\text { Acadêmico }\end{array}$ & $\begin{array}{l}\text { Análise Ambiental de Bacias } \\
\text { Hidrográficas } 60 \mathrm{~h}-10 \text { sem. }\end{array}$ & $\begin{array}{l}\text { (...) programas de monitoramento em } \\
\text { pequenas bacias hidrográficas. (...) }\end{array}$ \\
\hline \multirow{4}{*}{$\begin{array}{l}\text { Fitossanidade - } \\
\text { Mestrado Acadêmico }\end{array}$} & $\begin{array}{l}\text { Impacto Ambiental da } \\
\text { Agricultura } 68 \mathrm{~h}-1^{\circ} \text { semestre }\end{array}$ & $\begin{array}{l}\text { (...) dinâmica de agrotóxicos no } \\
\text { ambiente; Remediação da } \\
\text { contaminação ambiental (...) }\end{array}$ \\
\hline & $\begin{array}{l}\text { Dinâmica de Herbicidas no } \\
\text { Ambiente } 68 \mathrm{~h}-1^{\circ} \text { semestre }\end{array}$ & $\begin{array}{l}\text { (...) impacto ambiental de herbicidas } \\
\text { (...) destino ambiental de pesticidas. }\end{array}$ \\
\hline & $\begin{array}{l}\text { Entomologia Econômica } 68 \mathrm{~h}- \\
2^{\circ} \text { semestre }\end{array}$ & $\begin{array}{l}\text { (...) Impacto ambiental de plantas } \\
\text { transgênicas sobre inimigos naturais. }\end{array}$ \\
\hline & $\begin{array}{l}\text { Dinâmica de Herbicidas no } \\
\text { Ambiente } 68 \mathrm{~h}-1^{\circ} \text { semestre }\end{array}$ & $\begin{array}{l}\text { (...) impacto ambiental de herbicidas } \\
\text { (...) destino ambiental de pesticidas. }\end{array}$ \\
\hline $\begin{array}{l}\text { Manejo e } \\
\text { Conservação do Solo } \\
\text { e da Água (MCSA) }\end{array}$ & \multicolumn{2}{|c|}{$\begin{array}{l}\text { Diversas (Avaliação de Impactos Ambientais 68h, Avaliação e } \\
\text { Recuperação de Áreas Degradadas } 68 \mathrm{~h} \text {, Conservação do Solo e da } \\
\text { Água 68h, Gestão de Recursos Hídricos } 68 \mathrm{~h} \text {, entre outros) }\end{array}$} \\
\hline $\begin{array}{l}\text { Recursos Hídricos - } \\
\text { Mestrado Acadêmico }\end{array}$ & $\begin{array}{l}\text { Impactos Ambientais no } \\
\text { Aproveitamento de Recursos } \\
\text { Hídricos } 51 \mathrm{~h} \text { - Optativa }\end{array}$ & $\begin{array}{l}\text { (...) Dano Ambiental e Impacto } \\
\text { Ambiental (...) Aproveitamento de } \\
\text { recursos Hídricos. }\end{array}$ \\
\hline \multirow{3}{*}{$\begin{array}{l}\text { Sistema de Produção } \\
\text { Agrícola Familiar } \\
\text { (SPAF) }\end{array}$} & $\begin{array}{l}\text { Gerenciamento e Tratamento } \\
\text { de resíduos sólidos na } \\
\text { propriedade rural } 34 \mathrm{~h}-1^{\circ} \\
\text { semestre }\end{array}$ & $\begin{array}{l}\text { (...) resíduos sólidos (...) Plano de } \\
\text { Gerenciamento de Resíduos Sólidos } \\
\text { (...) compostagem (...) }\end{array}$ \\
\hline & $\begin{array}{l}\text { Desenvolvimento Rural } \\
\text { Sustentável } 68 \mathrm{~h}-2^{\circ} \text { semestre }\end{array}$ & $\begin{array}{l}\text { (...) sustentabilidade, agroecologia e } \\
\text { da agricultura sustentável. }\end{array}$ \\
\hline & $\begin{array}{l}\text { Sistemas de Produção de } \\
\text { Base Ecológica } 68 \mathrm{~h}-2^{\circ} \\
\text { semestre }\end{array}$ & $\begin{array}{l}\text { (...) pensamento agroecológico (...) } \\
\text { Agricultura Sustentável (...) } \\
\text { economia ecológica (...) }\end{array}$ \\
\hline
\end{tabular}

Fonte: autoria própria. 
Deve-se ressaltar que em relação aos PPG de MCSA e SPAF, não houve especificação na resposta do discente se este cursava em nível de Mestrado ou Doutorado, portanto considerou-se as disciplinas apresentadas pelo programa como um todo. Além disso, optou-se por ocultar sobre os "Objetivos Gerais", já que esse quesito não se encontrava disponível, apenas "Ementa". Em relação às disciplinas, no mesmo sentido do rumo tomado pelos demais cursos, há vasta presença de termos relacionados à sustentabilidade $\mathrm{e}$ impactos ambientais causados pela área de estudo. Por fim, o Mestrado de Ciências Ambientais apresenta uma disciplina sobre EA, relacionando com a área sanitária, totalizando no estudo cinco cursos com seis disciplinas específicas voltadas à EA.

\section{Considerações Finais}

A partir do estudo desenvolvido, foi verificado que a vasta maioria dos cursos participantes da pesquisa, mais precisamente $73,49 \%$, não fazem menção à PNEA em seus Projetos Político Pedagógicos. Deve-se destacar, inclusive, a ausência de um PPC elaborado em 19,28\% dos cursos, reduzindo a possibilidade de analisar a presença e adequação a esta lei. Concomitantemente, foi possível observar a presença de disciplinas com abordagem ambiental em $66,27 \%$ desses cursos. Destacam-se, ainda, os cursos de Licenciatura, em que apenas $25 \%$ possuíam essas disciplinas, e somente os cursos de Ciências Biológicas e Geografia possuem a disciplina de $E A$, fundamental para a formação de futuros docentes.

Já em relação aos cursos de Bacharelado e Tecnológico, obteve-se uma maior presença dessas disciplinas, com $71,70 \%$ e $100 \%$ dos cursos, respectivamente, auxiliando na inserção do futuro profissional no mercado de trabalho, introduzindo ao discente um posicionamento quanto o cenário ambiental do país atualmente. Deve-se apontar, ainda, a ausência dessas disciplinas nos cursos da área da saúde (Enfermagem, Medicina e Odontologia), fator preocupante devido à periculosidade do gerenciamento inadequado de RSS à saúde pública e ao ambiente.

Por fim, $66,67 \%$ dos cursos de Programas de Pós-Graduação apresentam disciplinas que abordam a temática ambiental. Ambas as discussões são relevantes para os discentes dos PPG, já que estes indivíduos possuem as seguintes opções: permanecer no campo acadêmico ou ingressar no mercado de trabalho. Portanto, a abordagem da temática ambiental é fundamental para a formação de todos os acadêmicos acolhidos pelas Instituições de Ensino Superior no país, seja qual for a área de conhecimento escolhida.

A partir disso, considera-se que a Universidade deve reafirmar seu papel como entidade formadora de cidadãos responsáveis, observando a necessidade e a importância da abordagem ambiental na formação dos mais diversos cursos, principalmente no que tange o reconhecimento da PNEA, 
reforçando a ideia de cuidado com o meio ambiente através da EA e, assim, aprimorando a percepção ambiental dos estudantes, visando uma formação ética e comprometida a sustentabilidade.

\section{Referências}

AMEM, B. M. V.; NUNES, L. C. Tecnologias de Informação e Comunicação: contribuições para o processo interdisciplinar no ensino superior. Rev. bras. educ. med., Rio de Janeiro, v. 30, n. 3, p. 171-180, dez 2006.

BERNARDES, M. B. J.; PRIETO, E. C. Educação Ambiental: disciplina versus tema transversal REMEA - Revista Eletrônica do Mestrado em Educação Ambiental, [S.I.], v. 24, set. 2013. ISSN 1517-1256.

BRAGA, B. et al. Introdução à engenharia ambiental. 1. ed. São Paulo: Prentice Hall, 2002. 318 p.

BRASIL. Constituição da República Federativa do Brasil, de 05 de outubro de 1988.

BRASIL. Lei № 12.305, de 02 de agosto de 2010. Institui a Política Nacional de Resíduos Sólidos; altera a Lei no 9.605, de 12 de fevereiro de 1998; e dá outras providências. Brasília: Diário Oficial, 02 de agosto de 2010.

BRASIL. Lei no 9.795, de 27 de abril de 1999. Dispõe sobre a Educação Ambiental, institui a Política Nacional de Educação Ambiental e dá outras providências. Brasília: Diário Oficial, 28 de abril de 1999.

BRASIL. Ministério da Saúde. Agência Nacional de Vigilância Sanitária. Manual de gerenciamento de resíduos de serviços de saúde. Brasília, 2006.

BRASIL. Programa Nacional de Educação Ambiental. 3 ed. Brasília: Coordenação Geral de Educação Ambiental, 2005.

CARVALHO, J. R. M. et al. Percepção da Educação Ambiental: um estudo junto aos discentes de pós-graduação de uma IES no Estado da Paraíba. Revista Gestão \& Sustentabilidade Ambiental, [S.I.], v. 4, n. 2, p. 234-253, out. 2015.

DALTOÉ, M. F. et al. Resíduos sólidos na rede de microdrenagem: uma análise qualitativa na cidade de Pelotas/RS. Revista Monografias Ambientais, [S.I.], p. 175-188, fev. 2016.

DIÁRIO POPULAR. Falta conscientização e também lixeiras - Estudantes têm depositado nos canteiros da redondeza as cascas das frutas recebidas no Restaurante Universitário. Diário Popular, Pelotas, RS. 19 de junho de 2018.

GERHARDT, T. E.; SILVEIRA, D. T. Métodos de pesquisa. Plageder, 2009. $120 \mathrm{p}$.

GIL, A. C. Como elaborar projetos de pesquisa. 4. ed. São Paulo: Atlas, 2007. $176 \mathrm{p}$. 
LEFF, E. Saber Ambiental: sustentabilidade, racionalidade, complexidade, poder. Petrópolis, RJ: Vozes, 2001. 343 p.

LEVINE, D. M. et al. Estatística: Teoria e Aplicações usando Microsoft Excel em Português. Rio de Janeiro: LTC, 2000. 804 p.

MEDINA, N. M. Elementos para a introdução da dimensão ambiental na educação escolar-1ํ grau. Amazônia: uma proposta interdisciplinar de Educação Ambiental. Brasília, IBAMA, 1994.

MORALES, A. G. M. O processo de formação em Educação Ambiental no ensino superior: trajetória dos cursos de especialização. REMEA - Revista Eletrônica do Mestrado em Educação Ambiental, [S.I.], v. 18, abr. 2013.

SILVA, A. D. V. et al. Percepção ambiental como ferramenta para processos de Educação Ambiental na universidade. REMEA - Revista Eletrônica do Mestrado em Educação Ambiental, [S.I.], v. 27, dez. 2012.

UNESCO. United Nations Educational, Scientific, and Cultural Organization. 1977. Intergovernmental Conference on Environmental Education. Disponível em: <http://unesdoc.unesco.org/images/0003/000327/032763eo.pdf>. Acesso em: 05 set. 2019.

UNIVERSIDADE FEDERAL DE PELOTAS. Institucional - Histórico. Disponível em: <http://portal.ufpel.edu.br/historico/>. Acesso em: 08 mai. 2019.

VEIGA, I. P. A. et al. Inovações e projeto político-pedagógico: uma relação regulatória ou emancipatória? Cadernos Cedes, v. 23, n. 61, p. 267-281, dezembro 2003. 